\title{
Our Single-Port Video-Assisted thoracoscopic surgery applications in the treatment of pneumothorax
}

\section{Pnömotoraks Tedavisinde Tek Port Video Yardımlı Torakoskopik Cerrahi}

\section{Uygulamalarımız}

\author{
Bayram METiNN ${ }^{1}$, Şener YILDIRIM ${ }^{1}$, Çiğdem ÜNAL KANTEKIN² ${ }^{2}$ Halil TÖZÜM³
}

\begin{abstract}
In recent years, single-port VATS (video-assisted thoracoscopic surgery) applications have become widespread in the surgical treatment of spontaneous pneumothorax. In this study, the results of 16 patients with spontaneous pneumothorax who were treated by single-port VATS were analyzed retrospectively. Fourteen $(87.5 \%)$ of the patients were male, $2(12.5 \%)$ of them were female, the average age of the patients was 28.50 (minimum: 18, maximum 63). All patients were evaluated according to the affected side of the chest, preoperative clinical characteristics, surgical procedures, postoperative clinical characteristics and recurrence rates during the follow-up period. More than half (56.3\%) of the patients had a right and $43.82 \%$ of them a left pneumothorax.The mean operation time ( $38.75 \mathrm{~min}$ ), length of surgical incision $(2.5 \mathrm{~cm})$, average amount of drainage (185.25 $\mathrm{ml})$, mean postoperative duration of indwelling drain (4.13 days), and mean postoperative hospital stay (5.13 days) were also estimated as included in parentheses. The patients suffered from mild (62.5\%), moderate (12.5\%), and severe pain (25\%) according to their visual analogue scale (VAS) pain scores calculated within the first 24-hours. There was no recurrence in any patients during a mean of postoperative follow-up period of 12.50 months. Single-port VATS applications with advantages of shorter port incision length, operation, and drainage time and shorter hospital stay will become commonly used in the treatment of pneumothorax thanks to development of new surgical equipment and increased experience in the future.
\end{abstract}

Key words: Video-assisted thoracoscopy, pneumothorax, single-port öz

Son yıllarda spontan pnömotoraksın cerrahi tedavisinde tek port VATS (video yardımlı torakoskopik cerrahi) prosedürlerinin kullanımı yaygınlaşmaya başlamıştır. Bu çalışmada, kliniğimizde tek port VATS ile tedavi edilen 16 spontan pnömotorakslı hastanın kayıtları retrospektif olarak incelendi. Olguların 14 (\%87,5)'ü erkek, 2 (\%12,5)'si kadın, yaş ortalaması 28,50 (minimum: 18 maksimum 63) idi. Tüm hastalar pnömotoraksın tarafına, preoperatif klinik özelliklerine, cerrahi prosedürlerine, postoperatif klinik özelliklerine ve takipteki nüks oranlarına göre değerlendirildi. Olguların \%56,3'ünde sağ, \%43,8'inde sol pnömotoraks vardı. Operasyon süresi ortalama 38,75 dk., cerrahi insizyon boyutu ortalama $2,5 \mathrm{~cm}$, drenaj miktarı ortalama $185,25 \mathrm{ml}$, postoperatif dren kalış süresi ortalama 4,13 gün, postoperatif hastanede kalış süresi ortalama 5,13 gün olarak hesaplandı. Ilk 24 saatte Görsel Analog Skala (VAS) ağrı skoruna göre hastaların \%62,5'inde düşük şiddetli ağrı, \%12,5'inde orta düzeyde ağrı, \%25'inde şiddetli ağrı mevcuttu. Hastaların ortalama 12,50 aylık postoperatif takip süreleri boyunca hiçbir hastada nüks ile karşılaşılmadı. Pnömotoraks tedavisinde tek port VATS uygulamaları, ileride geliştirilecek yeni cerrahi ekipmanlar ve artacak tecrübeler ile daha kısa port kesi uzunluğu, ameliyat süresi, drenaj miktarı, dren süresi ve hastanede kalış süreleri ile daha yaygın kullanılır hâle gelecektir.

\section{INTRODUCTION}

Pneumothorax is a collection of free air in the pleural cavity with resultant pulmonary collapse. Spontaneous pneumothorax is divided into two types according to the presence or absence of an underlying
Anahtar kelimeler: Video torakoskopi, pnömotoraks, tek port

Received: 16.11 .2015

Accepted: 15.12 .2015

${ }^{1}$ Department of Thoracic Surgery, Bozok University, Faculty of Medicine

${ }^{2}$ Department of Anesteziology and Reanimation, Bozok University, Faculty of Medicine

${ }^{3}$ Department of Thoracic Surgery, Medeniyet University, Faculty of Medicine, Goztepe Training and Research Hospital

Yazışma adresi: Halil Tözüm, Department of Thoracic Surgery, Medeniyet University, Faculty of Medicine, Goztepe Training and Research Hospital, Istanbul e-mail: dr.thorax@gmail.com 
rodesis, thoracotomy and video-assisted thoracoscopic surgery (VATS) procedures are currently applied in the treatment of PSP 1. Surgical treatment should be considered in the first attack to prevent recurrence in patients with prolonged air leak (>5 days), recurrent pneumothorax, contralateral pneumothorax, bilateral pneumothorax, and also in pneumonectomized patients, in individuals exposed to occupational hazards (pilots, divers, etc.), and people living in rural areas far awaya from a health center. An axillary thoracotomy is mostly preferred and lateral thoracotomy is less preferred among surgical thoracotomy options. In the surgical treatment of spontaneous pneumothorax in recent years, as an alternative to thoracotomy with high morbidity, VATS has been used prevalently. Up to now input methods with two, three and four-ports have been frequently used as VATS applications. In recent years, single-port VATS procedure has become commonly used ${ }^{1-4}$. In this study, the results of 16 patients with spontaneous pneumothorax who were treated by single-port VATS in our clinic have been reported.

\section{MATERIALS and METHODS}

The records of 16 patients with spontaneous pneumothorax who underwent single-port VATS in the Department of Thoracic Surgery of Faculty of Medicine of Bozok University between March 2013 and June 2015 were analyzed retrospectively. Fourteen (87.5\%) patients were male, $2(12.5 \%)$ patients were female with an overall average age of 28.50 (18-63) years. In all patients, pediatric fiberoptic bronchoscope was inserted through the intubation tube following a double-lumen intubation, and single-lung ventilation was performed after controlling the localization of the intubation tube. In all patients, thoracic cavity was entered with a trocar through the incision made from the intersection of mid-axillary line and 6th intercostal space (mean: $2.5 \mathrm{~cm}$, minimum: $2 \mathrm{~cm}$, maximum: $4 \mathrm{~cm}$ ). Then the trocar was pulled back so as to keep the camera of the thoracoscope in the thorax, endoscopic instruments and staplers were easily passed from the edge of the camera. The bullous area was excised with the aid of staplers in patients with bullous formation (Figure 1). Apical wedge resection was definitely performed in patients without bullous formation (Figure 2). In all patients, pleurectomy was performed extending from the apical to the port hole so as to stay away from the internal mammary artery with the help of endoscopic dissectors and graspers (Figure 3). After the control of bleeding and air leakage, the operation was terminated by placing a chest drain through thoracoscopy incision. All lung tissue samples and pleural fragments were sent to the pathology laboratory for examination. After air leak was stopped, drains were routinely kept two more days and then they were pulled back. The control chest $X$-ray was taken after a day in patients whose drains were pulled back, and the patients without pneumothorax were discharged from hospital. After all patients were discharged, they were followed up at polyclinics on postoperative 10,30, 60, 90 days, 6 months, and one year.

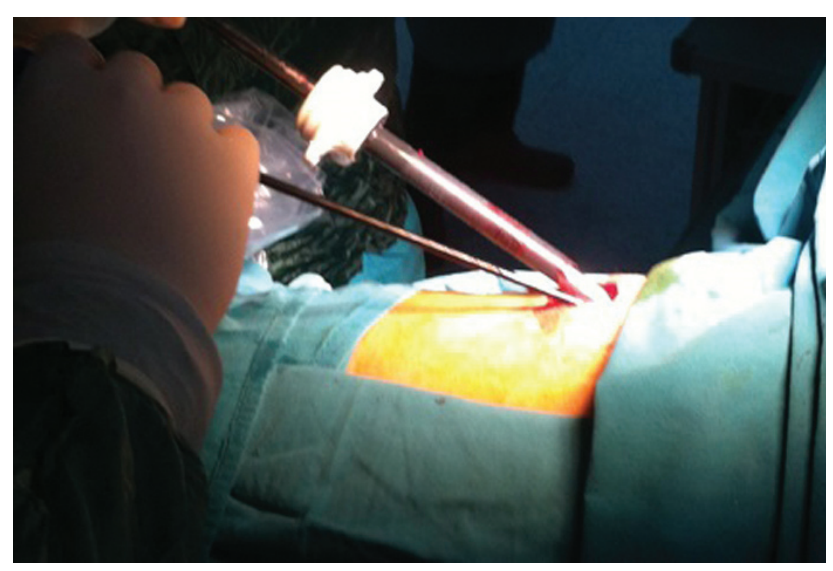

Figure 1. View of the operative field.

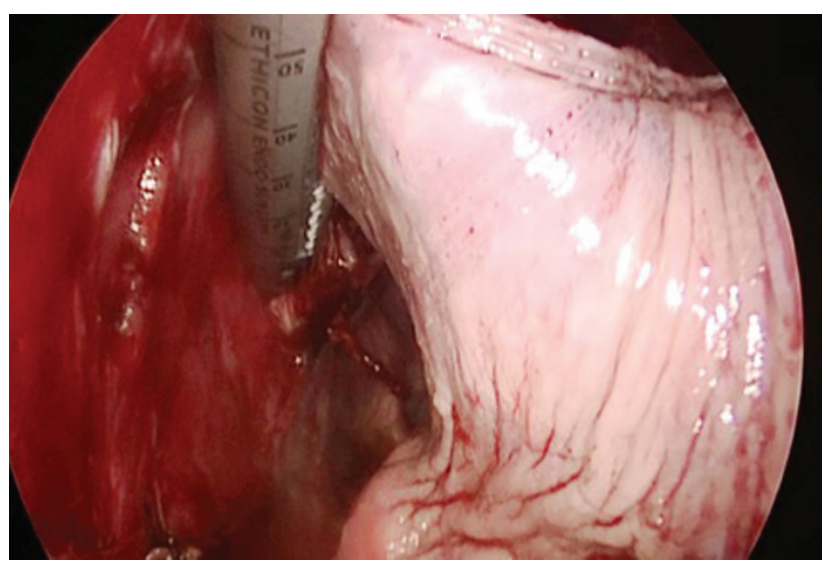

Figure 2. Apical wedge resection procedure with the help of stapler. 


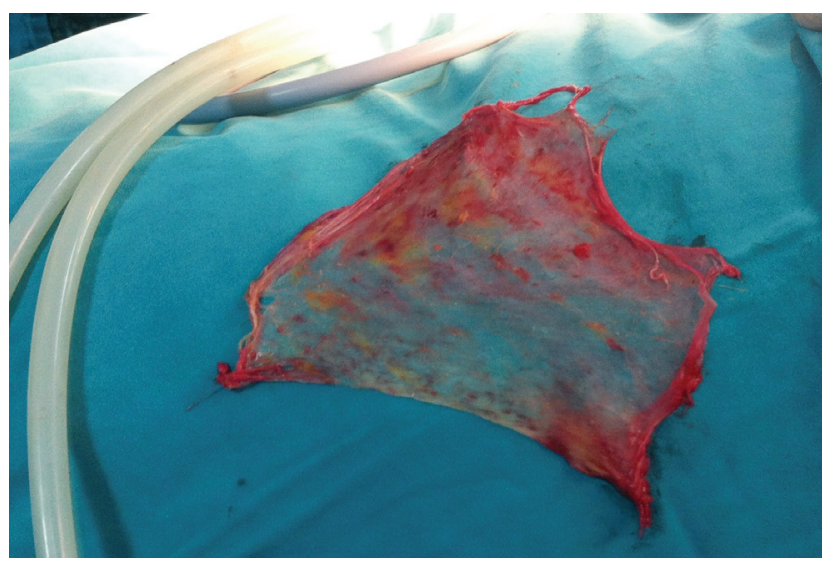

Figure 3. Parietal pleura extracted by performing apical pleurectomy.

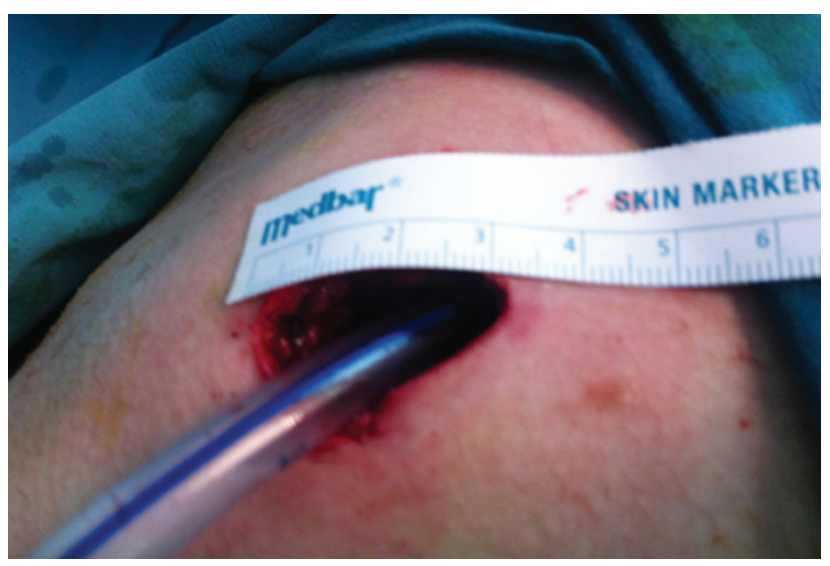

Figure 4. The mean size of the surgical incision was $2.5 \mathrm{~cm}$.

\section{RESULTS}

More than half $56.3 \%(n=9)$ of the patients had right, and $43.82 \%(n=7)$ of them left pneumothorax. While surgical procedures were performed in $56.3 \%(n=9)$ of the patients because of recurrences, surgical procedure was performed in $43.82 \%(n=7)$ of the patients due to prolonged air leak lasting more than 7 days. The mean operation time was 38.75 minutes (25-60 $\mathrm{min})$. Median length of the surgical incision was $2.5 \mathrm{~cm}(2-4 \mathrm{~cm})$ (Figure 4). Any major intraoperative complication did not occur. The average amount of drainage was measured as $185.25 \mathrm{ml}(100-600 \mathrm{ml})$. The median dwelling time of the postoperative drain was 4.13 days (3-13 days) which was extended up to 13 days in one of these patients due to the prolonged postoperative air leak. The median duration of postoperative hospital stay in patients was calculated as
5.13 days (3-15 days). Postoperative pain treatment was performed with intravenous paracetamol infused every 6 hours (Parol infusion). The pain during the first 72 hours was evaluated by visual analogue scale (VAS). Pain was classified as mild (0-4 pts), moderate (5-7 pts), and severe (8-10 pts) pain. Within the first the first 24 hours mild ( $62.5 \% ; n=10)$, moderate (12.5\%; $n=12.5)$ and, severe (25\%; $n: 4)$ pain was present in respective number of patients. Based on VAS scores at 48 hours, pain was of mild (81.3\%), and moderate (18.7\%) severity in respective number of patients, while none of the patients suffered from severe pain. Based on VAS scores at 72 hours, mild, and moderate pain was detected in 93.8 , and $6.2 \%$ of the patients, respectively. While pneumonia was observed in 1 (6.3\%) patient in whom the duration of drainage was extended up to 13 days due to postoperative prolonged air leak in the postoperative period. There was no any additional morbidity in the remaining 15 patients. There was no disease recurrence in any patients during median postoperative follow-up period of 12.50 months (minimum 2 mos, maximum 30 mos). There were no significant correlations between the incision length and the duration of the operation ( $p: 0.410)$, between the incision length and the VAS pain score at 24 hours ( $p: 0.447)$. between the incision length and the dwelling time of the postoperative drain ( $p: 0.228$ ), amad finally between the incision length and the amount of the drainage according to Pearson's correlation test ( $p: 0.399)$. In all patients, the histopathology results of the pleural specimens have been reported as active chronic pleuritis; and the parenchymal pathology results have been indicated as sub-pleural bullae formation, bleeding areas and anthracosis.

\section{DISCUSSION}

PSP is mostly seen in healthy, young, tall and thin men. It has been stated that the incidence rate was $18-28 / 100000$ in males, and $1.2-6 / 100000$ in females ${ }^{1,2}$.

The main goal in the treatment of primary spontaneous pneumothorax is to prevent air leakage into parenchyma and recurrence after evacuation of air contained in 
the pleural space ${ }^{3}$. There are many authors supporting that observation, aspiration and tube thoracostomy would be enough in the first attack in the treatment of primary spontaneous pneumothorax. While recurrence rate after the first attack is indicated as $23-50 \%$ in those treated with non-surgical methods, the probability of recurrence after 2 and more attacks rises to $60-80 \%^{1,2}$. The majority of surgeons prefer blebectomy/bullectomy and parietal pleurectomy or abrasion procedures in order to prevent recurrence. For this purpose, thoracotomy, multi-port VATS and single-port VATS (the latest method) have been used ${ }^{3}$. Although compared to VATS lower recurrence rates have been reported in thoracotomy, abundant amounts of blood loss, severe postoperative pain and longer hospital stay are disadvantages of thoracotomy ${ }^{1}$. VATS is a minimally invasive technique which has less postoperative pain and it is preferred more frequently thanks to its cosmetic results. Singleport VATS application is developing as an alternative to traditional practices. Endoscopic grasper, dissector, stapler, and camera are inserted into the thoracic cavity from single-port and bullectomy or blebectomy, pleurodesis, abrasion or pleurectomy are performed and the chest tube is inserted from the same incision. Singleport VATS was firstly applied in 6 patients with pneumothorax in $1998^{4,5}$. Because all instruments are under the control of the surgeon in single-port, it has been stated that a higher cooperation was provided during the use of other instruments with the camera ${ }^{6}$. In all of our patients, port was pulled back after a 30-degree camera was inserted into the chest without contaminating $10 \mathrm{~mm}$ port inserted through a median $2.5 \mathrm{~cm}$ incision and then we have performed operations by pushing forward our instruments all along the camera.

The postoperative recurrence rate was indicated as 0-17.9\% in single-port VATS applications for spontaneous pneumothorax ${ }^{6,8,9}$. Eighty percent of the postoperative recurrences have occurred within the first five postoperative months $s^{8}$. The recurrence rate is stated to be higher in children and in women ${ }^{1,9}$. Average age of our patients was 28.50 years and only 2 of our patients were female without any recurrence in our series of 16 cases. These outcomes were consistent with the relevant literature data.
It has been reported in early studies that this high recurrence rate in VATS group compared to the thoracotomy resulted from inadequate monitorization of blebs and bullae and bullectomy by VATS. However, it has been reported in recent studies that recurrence rates after VATS decreased with the developments in thoracoscopic instruments ${ }^{6,9}$. Moreover, it has been stated that postoperative recurrence may be secondary to smoking, the formation of bullae caused by antibodies against alpha 1 antitrypsinin in nonsmokers and abnormal degradation of elastic fibers of blebs ${ }^{8}$.

Some studies advocated that stapler line can be supported by different tissue adhesives, there is no clear consensus on that pleurodesis should be made by using, pleurectomy, pleural abrasion or chemical means. It has been specified in some studies that multiple applications were performed in the same case ${ }^{1}$. Protection of internal mammary artery in apical pleurectomy is stated to be important in terms of the probability of coronary artery disease which will occur in the future ${ }^{7}$. In all of our patients, we performed apical pleurectomy extending from apex to port level so as to protect the internal mammary artery anteriorly.

Since single-port VATS is performed through a single intercostal space it causes less pain ${ }^{3}$. Maximum pain score was determined using the VAS pain scoring system which is numbered between 0 and 10 . In studies performed, according to VAS pain scoring system milder pain has been reported for the singleport group ${ }^{5,6,11,12}$. In our cases in a way to support literature, lower pain scores were observed on postoperative 24, 48 and 2 hours in the majority of the cases according to VAS pain score. Moreover, there were also no significant correlations between the incision length and the VAS pain scores in the correlation tests performed in our cases ( $p: 0.447)$.

In some articles mean surgery times of 48.8 and 61.7 minutes have been reported in single-port VATS applications. The authors stated that operative times fro single-port applications were shortened to 30 minutes in recent cases ${ }^{6,10}$. Median operative time was $38.75 \mathrm{~min}$ in our study. As has been reported in the literature, in parallel with increases in our experien- 
ce operative time is shortened further and we could reduce the operative times to 25 minutes in our last cases. In our patients, there were also no significant correlations between the incision length and the operation time ( $\mathrm{p}: 0.410)$.

It has been stated in a study that the average amount of postoperative drainage was $150 \pm 170 \mathrm{ml}$ in singleport applications which was lower relative to other multi-port interventions thanks to lesser number of incisions ${ }^{6}$. The average amount of drainage was determined as $185.25 \mathrm{ml}$ in our cases. In our study, there were no significant relationships between the incision length and the amount of the drainage according to the correlation test ( $p: 0.399)$.

There are many studies indicating shorter drainage times in single-port groups compared to multi-port groups. In the literature, although the mean duration of postoperative drainage varies between 1-4.6 days, it has been stated that its duration was extended up to 15 days in those with postoperatively prolonged air leakage $\mathrm{e}^{3,6,11,12}$. In all our cases, we kept drain 2 more days in situ despite cessation of the air leakage and duration of drainage was calculated as 4.13 days in our study. Prolonged air leakage and pneumonia have developed in one of our cases and duration of the drainage was ${ }^{13}$ days in this patient. There were also no significant relationships between the incision length and the postoperative dwelling of the drain in the correlation test ( $p: 0.228)$.

Although the length of hospital stay reportedly ranged between 2-6 days, in complicated cases3length of hospital stay up to 60 days has been reported ${ }^{6,10}$. The average length of hospital stay of our patients was consistent with the literature and it was calculated as 5.13 days.

The length of surgical incision was stated to be between $2-4 \mathrm{~cm}^{3,6,10}$. The mean length of the surgical incision in our patients was $2.5 \mathrm{~cm}(2-4 \mathrm{~cm})$ in compatible with the literature. We believe that its length will decrease more by improvement in endoscopic surgical instruments technology in the future.
Small number of cases in our study is a limitation of our study with respect to age, and gender distribution and the evaluation of surgical procedures. Single-port VATS applications in the treatment of pneumothorax will become commonly used with the advantages of shorter port incision, operation, drainage, and hospitalization times, smaller amount of drainage, thanks to developments of new surgical equipments and increased experience in the future.

\section{REFERENCES}

1. Imperatori A, Rotolo N, Spagnoletti M, et al. Risk factors for postoperative recurrence of spontaneous pneumothorax related by video-assisted thoracoscopic surgery. Interact Cardiovasc Thorac Surg 2015;20:647-51.

http://dx.doi.org/10.1093/icvts/ivv022

2. Çobanoğlu U, Sayır F, Sertoğullarından B, et al. Eş zamanlı bilateral spontan pnömotoraks: 11 olgunun retrospektif analizi. J Clin Anal Med 2011;2:69-74. http://dx.doi.org/10.4328/JCAM.419

3. Kang DK, Min HK, Jun HJ, et al. Early outcomes of single-port video-sssisted thoracic surgery for primary spontaneous pneumothorax. Korean J Thorac Cardiovasc Surg 2014;47:384-8. http://dx.doi.org/10.5090/kjtcs.2014.47.4.384

4. Yamamoto $H$, Okada $M$, Tanada $M$, et al. Video-assisted thoracic surgery through a single skin incision. Arch Surg 1998;133:145-7.

http://dx.doi.org/10.1001/archsurg.133.2.145

5. Tamura M, Shimizu Y, Hashizume Y. Pain following thoracoscopic surgery: retrospective analysis between single-incision and three-port video-assisted thoracoscopic surgery. J Cardiothorac Surg 2013,8:153.

http://dx.doi.org/10.1186/1749-8090-8-153

6. Ocakcioglu I, Alpay L, Demir M, et al. Is single port enough in minimally surgery for pneumothorax? Surg Endosc 2015 (In Press). http://dx.doi.org/10.1007/s00464-015-4161-6

7. Paliouras D, Barbetakis N, Lazaridis G, et al. Video-assisted thoracic surgery and pneumothorax. J Thorac Dis 2015;7(Suppl 1):S56-61.

8. Haraguchi S, Koizumi K, Hioki M, et al. Postoperative recurrences of pneumothorax in video-assisted thoracoscopic surgery for primary spontaneous pneumothorax in young patients. J Nippon Med Sch 2008;75:91-5. http://dx.doi.org/10.1272/jnms.75.91

9. Noh D, Lee S, Haam SJ, et al. Recurrence of primary spontaneous pneumothorax in young adults and children. Interact Cardiovasc Thorac Surg 2015:21:195-9. http://dx.doi.org/10.1093/icvts/ivv104

10. Yamazaki K, Haratake N, Shikada Y, et al. Initial experience of single-incision thoracoscopic surgery for 100 patients with primary spontaneous pneumothorax. Ann Thorac Cardiovasc Surg 2015 (In Press). http://dx.doi.org/10.5761/atcs.oa.15-00063

11. Akter F, Routledge T, Toufektzian L, Attia R. In minor and major thoracic procedures is uniport superior to multiport video-assisted thoracoscopic surgery? Interact Cardiovasc Thorac Surg 2015;20:550-5. http://dx.doi.org/10.1093/icvts/ivu375

12. Jutley RS, Khalil MW, Rocco G. Uniportal vs. standard threeport VATS technique for spontaneous pneumothorax: comparison of post-operative pain and residual paresthesia. Eur J Cardiothorac Surg 2005;28:43-6.

http://dx.doi.org/10.1016/j.ejcts.2005.02.039 